\title{
Design for six sigma: A review
}

\author{
Kouroush Jenab ${ }^{a^{*}}$, Cuibing Wu $\mathbf{u}^{\mathrm{b}}$ and Saeid Moslehpour
}

${ }^{a}$ Faculty, Dept. of Engineering \& Technology Management, Morehead State University, Morehead, KY, USA

${ }^{b}$ Graduate Student, Dept. of Engineering \& Technology Management, Morehead State University, Morehead, KY, USA ${ }^{c}$ Faculty of College of Engineering, Hartford University, West Hartford, CT, USA

\section{H R O N I C L E \\ A B S T R A C T}

Article history:

Received: September 2, 2017

Received in revised format: September 26, 2017

Accepted: November 2, 2017

Available online:

November 2, 2017

Keywords:

Lean manufacturing

Six Sigma

Review

\begin{abstract}
Six Sigma is recognized as an essential tool for continuous improvement of quality. A large number of publications by various authors reflect the interest in this technique. Reviews of literature on Six Sigma have been done in the past by a few authors. However, considering the contributions in the recent times, a more comprehensive review is attempted here. The authors have examined various papers and have proposed a different scheme of classification. In addition, certain gaps that would provide hints for further research in Six Sigma have been identified. As a results the relationship between Six Sigma, Design for Six Sigma (DFSS), and how these two concepts support the quality system for organizational learning and innovation performance have been discussed that would help researchers, academicians and practitioners to take a closer look at the growth, development and applicability of Six Sigma in Design.
\end{abstract}

\section{Introduction}

Numerous researchers have avowed that the Six Sigma strategy is a potentially useful tool for fostering learning. In turn by improving the learning process it escalates a company's competitive advantage. Fast changing markets require the progress of technological innovation, and shorter product lifecycles always challenge the competitive advantage. The basic philosophy of any business is to operate in the black and not the red. In order to do this one has to have an understanding of the inputs and outputs of that organization. This is also referred to in the term of throughput, which is the process of all implications dealing with the development of a finished good. The input is transformed into the output. The input is labor, material, machine and energy that is used and products/services that are acquired at the end of the transformation in order to operate in the black the value of the output must be more than the value of the inputs used (Barbara et al., 1992).

Six Sigma is used multiple different ways for multiple different reasons (Kihn, 2005). It is a measurement of quality that creates flawlessness within organizations. It can be anything outside of customer

* Corresponding author. Tel: (606)783-9339, Fax: (606)783-5030

E-mail address: k.jenab@moreheadstate.edu (K. Jenab) 
specifics. Six Sigma uses a specific process to test defects in order and receive perfection. It became popular in the mid 90's (Gowen III et al., 2008; Guarraia et al., 2009; Carney, 2001; Eckes, 2003). It works by collecting data and analyzing data affectively (Aksoy \& Dinçmen, 2011). Six Sigma uses methodology to reduce waste, improve, and increase customer satisfaction with overall finically results. Six Sigma improves effectiveness, efficiency, and innovation in industries (Zhang \& Xu, 2008). In this new century, technology, innovations, structural change, and competition are constantly changing (Kemper \& de Mast, 2013). Therefore, customers' expectations are consistently changing. This forces companies to manage their company's routine operations. So companies must have an effective and efficient system to consistently development improvement. Many companies wish to learn what Six Sigma can do for them, how to effectively use it, why to use it, and to define it (Gutiérrez et al., 2012). Six Sigma is a worldwide approach used by any and everybody or organization that is willing to adopt the strategic method of doing business. Six Sigma modifies product quality, customer satisfaction, funding, capital spending, and overall company growth (Caulcutt, 2001). It has saved industries millions, and sometimes billions of dollars over time. Six Sigma is successful, because it has more than one focus. Some of Six Sigma's main focuses include: management on every level, values and objectives, customer satisfaction, performance, and growth. Six Sigma was helped companies achieves success beyond imaginable dreams.

Quality is extremely important within Six Sigma (Goh, 2010; Apley \& Kim, 2011). Quality can determine overall success of a company. If a product does not contain great quality it will not last long on the market, and the company could end up losing more profit than it gains (Davison \& Al-Shaghana, 2007). Everyone wants good quality in a product or service. For example, when it comes to fashion quality is an important aspect. There are two different companies that make the same type of athletic running tennis shoe. One shoe is more durable and last longer than the other, therefore more people are going to buy the better shoe. The better shoe company is going the also make more money, and the other shoe company is going to lose money. They also are going to have to sell their product at a cheaper value.

There are many different statistical solutions to improve Six Sigma (Flynn et al., 1995; Goh, 2010). The fundamental aspect of Six Sigma is extremely important. It is not easy to master the statistical part of effectively. Some companies have a hard time achieving success from Six Sigma, and sometimes even fail. Mass production can lead to failure. Some companies make wrong business decisions, waste time and money, and sometime do not have good software, which can also lead to failure (Furterer \& Elshennawy, 2005).

Companies front a big cost to purchase and implement a Six Sigma program. To offset the huge upfront cost of Six Sigma is to have a successful Six Sigma program. This in the long run will out weight the cost of purchasing and implementation of a Six Sigma program. Table 1 is a sample list of some companies who implemented Six Sigma and also the originating company of Six Sigma (Sunder, 2013a, 2013b):

\section{Table 1}

Companies and the Year They Implemented Six Sigma

\begin{tabular}{lc}
\hline Company Name & Year Began Six Sigma \\
\hline Motorola (NYSE:MOT) & 1986 \\
Allied Signal (Merged With Honeywell in 1999) & 1994 \\
GE (NYSE:GE) & 1995 \\
Honeywell (NYSE:HON) & 1998 \\
Ford (NYSE:F) & 2000 \\
\hline
\end{tabular}

This review is conducted by categorizing published literature on Six Sigma, Design for Six Sigma (DFSS) and quality management. The collected publications listed include research papers, conference 
proceedings, technical reports, journals, and books from 1992 to 2015. Fig. 1 depicts the numbers of publications in five-year interval and Fig. 2 shows the key words frequency in references.

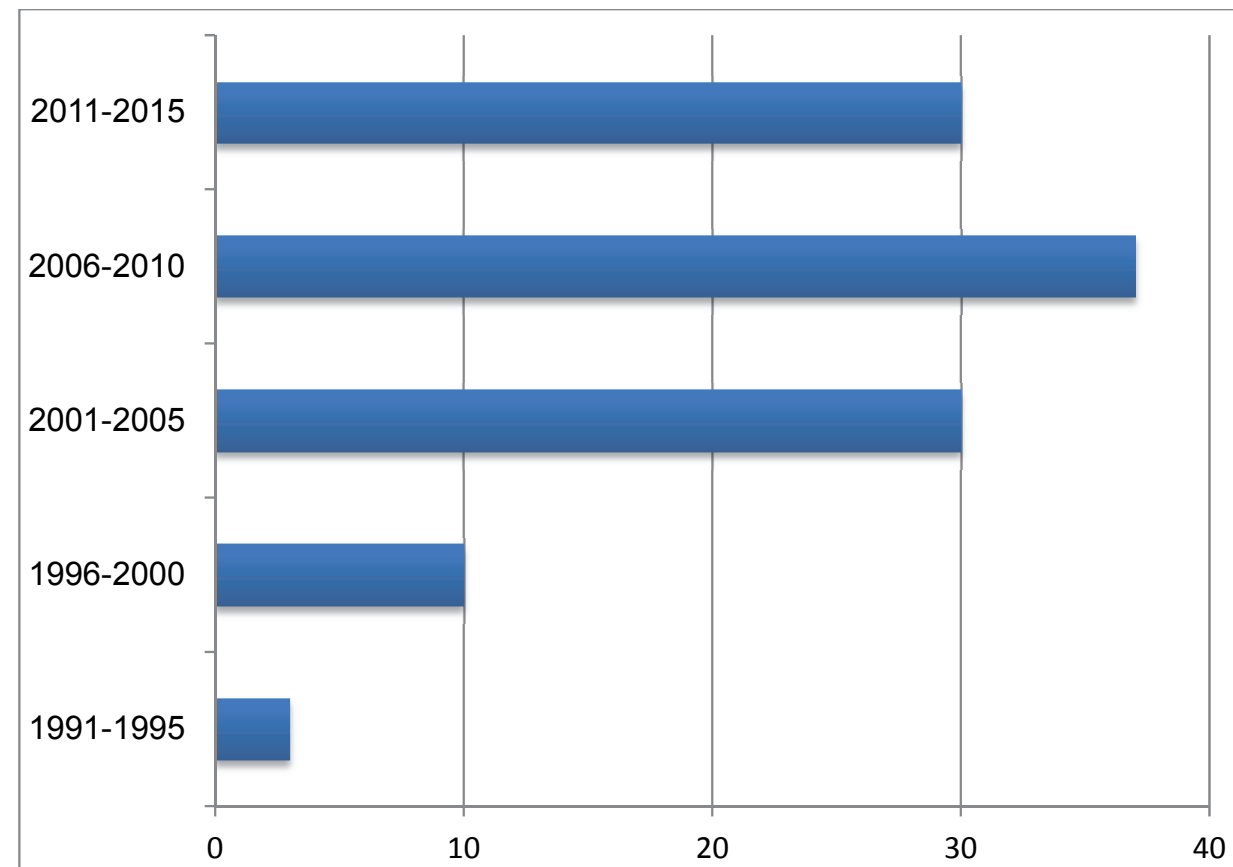

Fig. 1. Numbers of publications in five-year interval

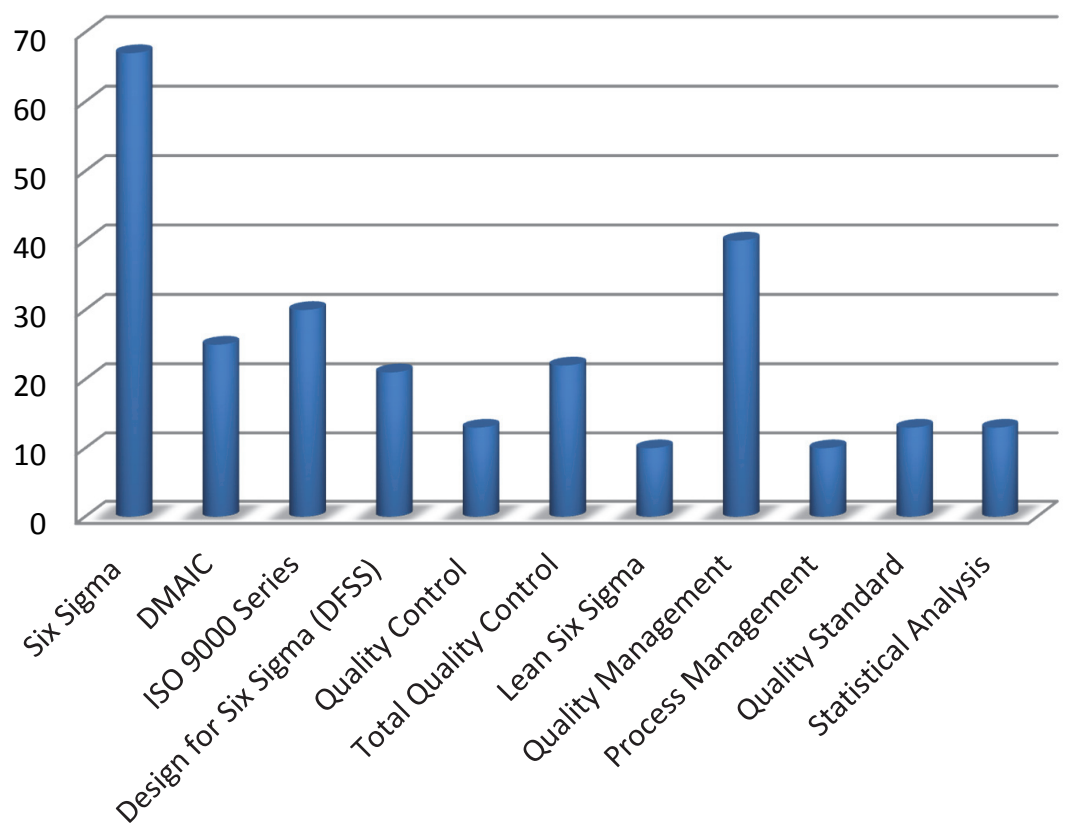

Fig. 2. Key words frequency in references 


\section{Six Sigma}

Six Sigma refers to the philosophy and methods companies use to eliminate defects in their products and processes (Furterer \& Elshennawy, 2005; Sampaio et al. 2009). To help explain this first we must clarify what a defect is. A defect is simply any component that does not fall within the customer's specifications for what they desire to have in a purchased finished good. In a finished goods process to becoming a finished good every step that it goes through, whether it is in the design process or in the assembling process, is an opportunity for a defect to occur. Here is a list of some examples of a manufacturing facility in which there could be a defect (McAdam \& Evans, 2004):

* The initial sales representative could leave something out of the sale;

* In the design process there can be stuff added or accidently left out;

* In the purchasing of the raw materials something could be left out;

* The raw material could be of a lower grade of material if cutting cost;

* At every step of producing the good a process could have a blemish;

* When assembling the finished good a piece could be left out;

* On the delivery end it could be damaged if not handled properly;

* Part of the shipment could be delivered to the wrong facility;

* The customer satisfaction representative could miss handle the follow up call;

All these areas could become an area for a defect, which would affect the customer's satisfaction and ultimately a company could lose the customer, which would affect the bottom dollar. Six Sigma is designed to reduce the variation in the processes that lead to these defects (Schall, 2012; Apley \& Kim, 2011; Snee, 2011). Six Sigma means 3. 4 defects are produced for million opportunities in the processes (Wang et al., 2014; Barbara et al., 1992). This process allows companies to determine the performance of their company using a common metric process. This common metric process is called defects per million opportunities (DPMO) (Caulcutt, 2001; Barbara et al., 1992; Karthi et al., 2012; Anand et al., 2012). In order to run this calculation, it requires three pieces of data; Unit, Defect, and Opportunity (Pisani et al., 2009; Moosa \& Sajid, 2010).

Six Sigma is constantly growing. Some of Six Sigma's characteristics include process management and teamwork (Gutiérrez et al., 2012). It has also been considered as management philosophy. Teamwork is extremely important. It inspires workers to share knowledge associated to their work responsibilities (Gutiérrez et al., 2010). Once the information is shared amongst each associate they use it to their own advantage to creative new innovative ideas to improve the company. Teamwork is a huge factor in the Six Sigma process. Six Sigma teamwork is a different from the quality management teamwork because of creating specialized positions, carrying by employees, and running the projects instead of overloading the firm's managers of Six Sigma teamwork (Gutiérrez et al., 2012). It shows successful elucidations and show that the implements and abilities learned work well together.

Therefore, the Six Sigma process management requires firm statistical methodologies of experimentation and study (Bhuiyan \& Nadeem, 2004). From a statistical perspective, Six Sigma is the best method for quality improvement (Gutiérrez et al., 2012).

(1) To clarify how executives perceive Six Sigma in practice for the meaning of Six Sigma and what is the manifestation under the umbrella of Six Sigma.

(2) To identify success factors with particular reference to industry's perception of success for Six Sigma implementation and how to measure it (Ravichandran, 2006). And at the start of the Six Sigma implementation, what the level of quality improvement experience and which factors to influence the sustainability of a Six Sigma approach are.

(3) In order to assess to what extent Six Sigma is a transnational improvement methodology, identify differences and commonalities between various countries (Van Iwaarden, 2008). 
Employee engagement is also an important feature of Six Sigma and development (Sunder, 2013a). Employee satisfaction includes compensation or pay, opportunities to use skills and abilities, management recognition of employee job performance, communication between employees and senior management, work itself, and relationships with co-workers. Stages of Six Sigma development include: roll out of Six Sigma training program, business opportunities, and project identification, project execution, leadership buy-in and Six Sigma team formation, and Six Sigma Certification. Total employee engagement becomes critical. Six Sigma has a huge positive impact on the organization's human resources and a study reveals it when the rightly embedded in the organization's culture (Sunder, 2013a,b; Davison \& Al-Shaghana, 2007). Therefore, Six Sigma requires a structured approach for success.

\subsection{Six Sigma Methodology}

While Six Sigma methodology includes many of the statistical tools that were and are employed by other quality movements, here they are used in a more systematic project-oriented fashion using the; define, measure, analyze, improve, and control (DMAIC) cycles (Gowen III et al., 2008; Anand et al, 2007; Atkinson, 2014; Canato et al., 2013; Chang et al., 2012; Halliday, 2001; Krishnamoorth, 2011). This process is ultimately the purpose of every organization that deals with producing a finished good for a customer. Here is a standard approach to be used when using the DMAIC approach (Nandi et al., 2014; Chen et al., 2008; Galli \& Handley, 2014; Herman, 2007; Isakson, 2004; Kanigolla et al., 2013; Kumar et al., 2009; Plotkin, 1999).

\section{1. (D) Define}

Identify the customer's wants and standards.

Next pick a project that is suitable for Six Sigma based on business objectives as well as the customer's desires and feedback.

Identify critical-to-quality characteristics (CTQs) that the customer feels to have the most impact on quality (Rajagopalan et al., 2004).

2. (M) Measure

Determine how to measure the process and its performance.

Identify the key internal process that influence CTQs and measure the defects currently generated relative to those processes.

3. (A) Analyze

Figure out what is the most likely cause of a defect.

Understand why analyzing the key variables that are most likely to create process variation generates defects.

4. (I) Improve

Figure our means to remove the causes of a defect.

Confirm the key variables and quantify their effects on CTQs.

Set the maximum acceptable ranges of the key variables and create a system for measuring deviations of the variables.

Modify the process if needed to stay within acceptable ranges.

\section{5. (C) Control}

Figure out how to maintain the improvements.

Put tools in place to ensure that the key variables remain within the maximum acceptable ranges under the modified process.

Some of the basic tools used in Six Sigma are: flowcharts, run charts, Pareto charts, check sheets, causeand-effect diagrams, opportunity flow diagram, process control charts, and failure mode and effect analysis and design of experiments (Schall, 2012; Pisani et al., 2009; O'Neill et al., 2012; Parihar \& Bhar, 2014; Park et al., 2009). 


\subsection{Challenges of Six Sigma}

Even though Six Sigma has several benefits it also has some drawbacks. The first and biggest drawback is the purchase and implementation cost. The other aspect that an organization should look into is that a Six Sigma program is not a get rich quick program. In fact it is more of a long-term financial goal (Kumar et al., 2011; Shah et al., 2008). However, if a company can afford it and can wait out the storm then it is typically a profitable avenue to venture down. Most times it earned savings of $1.4 \%$ to $5 \%$ for companies that took the time to implement it correctly.

\subsection{Design for Six Sigma (DFSS)}

DFSS is the acronym for Design for Six Sigma (Terziovski \& Samson, 1999; Vasilash, 2003; Grant \& Mergen, 2009). Design for Six Sigma is when a company tries to design or re-design new services or products to make a job or process easier (Jou et al., 2010; Meeting and show, 2009). In DFSS it is good to understand the needs of customers and construct a new way of doing things with the authenticity of distribution before delivery rather than after (Jusko, 2002; Owens, 2011; Park \& Gil, 2006).

DFSS is not really a methodology. It is an attitude and an approach to delivering new products and services to customers with a high performance that is measured by customers and is critical to quality measures (Chung \& Hsu, 2010). DFSS does also have a methodology though in which new products and services can be formed and carried out (Boisvert, 2005; Burnette, 2009).

When one thinks of design, it is usually associated with products more than services. Companies are beginning to realize that all products have associated services and this matters as much to the customer as the product. DFSS is not only used in big companies but small companies/stores can use this method as well. As a business starts with the DFSS process, it has to consider every aspect of the business strategy, from the introduction of the new product right down to the commercialization. All good DFSS methodology must work as a framework for all types of designs and for the products and services (Kuei et al., 2011; Bossert, 2013).

When a new product is introduced or re-introduced, DFSS can be used in the process. Design and development of new products are very much a part of everyday life in a company. The adopting and using of DFSS can considerably improve the designing and implementing process. There are many degrees of design within any commercial environment. This means there will be many different levels or 'flavors' of DFSS. With this in mind, projects can range from small projects or very large projects that consist of major designs of new and complex products and/or services. Projects that are large DFSS projects are best utilized for the establishment of new products/services with extensive design and great impact and there is a customer requirement approval of high levels of performance and delivery (Dick et al., 2008). There are certain tools required in the use of DFSS. There is strong emphasis placed on the analysis of customers. Transition of customer needs and the requirements (of the product services) right down the process requirements. Error and failure proofing is also needed by the customer (Jolin, 2009). The product/series are often generally new so modeling and simulation tools are important, especially for measuring and testing in advance the likely process of the new product/services. The main tools include simulation techniques, Design of Experiment (DOE), Quality Function Deployment (QFD) and Failure Mode Effect Analysis (FMEA) (Johnson et al., 2006; Jones et al., 2010). DFSS methodologies in commercial design are about an approach that is deeper, wider and more integrated. Everyone, including customers, is involved in the process in order to deliver a better product/service and final implementation.

In order for DFSS to work successfully, it must cover the full process of all new products and/or services. It all starts when the organization agrees formally on the requirements of something new and ends when the new product/service has been delivered. The first thing is the introduction of the new 
product. After the product has been introduced, it has to be defined. The product then goes through concept analysis, the technical design, and then the implementation. When the product is fully implemented, it can then be handed over to the new owners as shown in Fig. 3. All of this can be achieved through good DFSS techniques and teamwork and the chart sheets as shown in Tables 2-5 (Caulcutt, 2001; Schall, 2012; Anand et al., 2007; Almaoui et al., 2013; Chang et al., 2012).

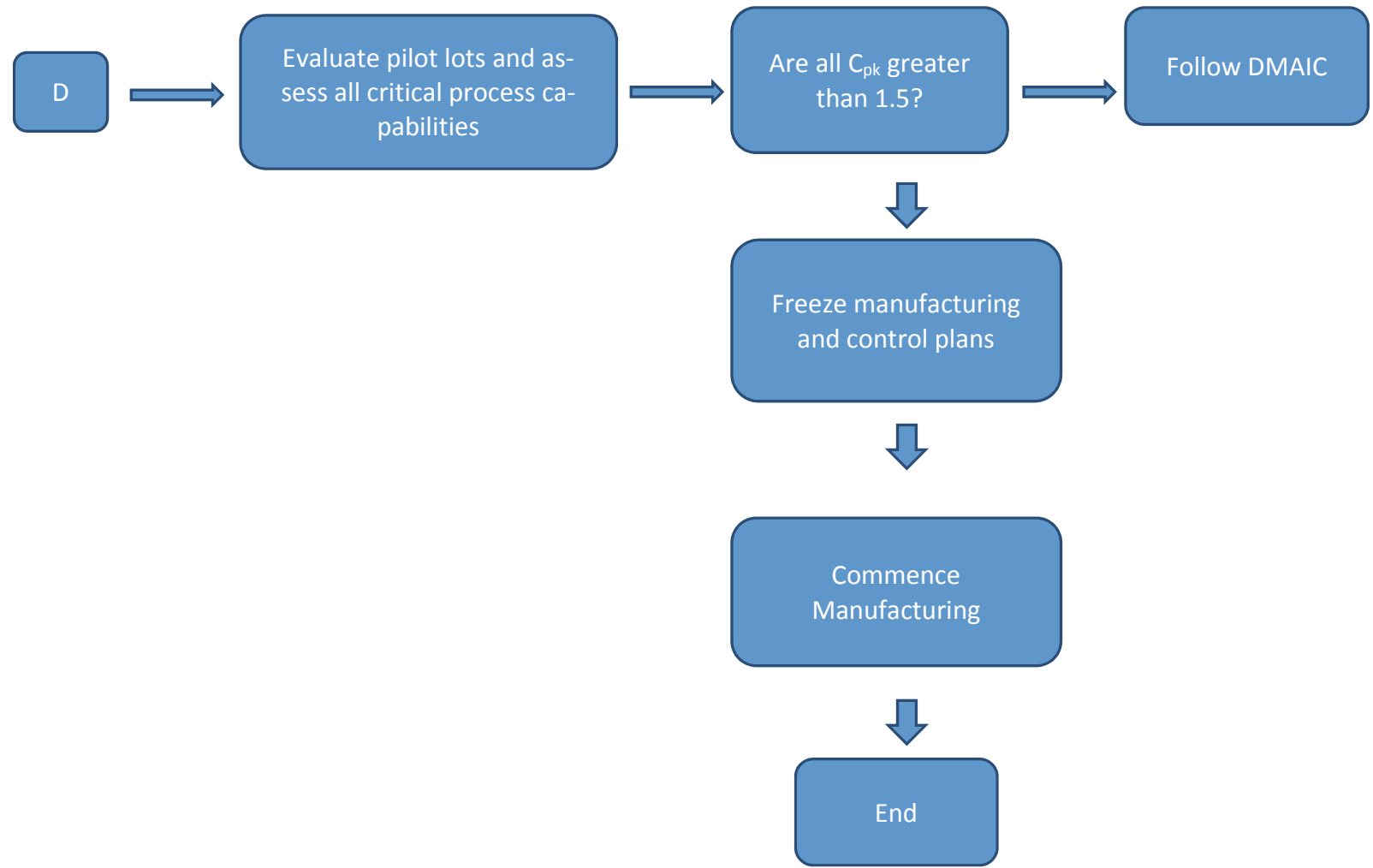

Fig. 3. DFSS in manufacturing processes

Table 2

Check Sheet (1) for Drawings

\begin{tabular}{|c|c|c|c|c|c|c|}
\hline $\begin{array}{l}\text { Num- } \\
\text { ber }\end{array}$ & Particulars & Yes & No & Action Required & Responsibility & Date \\
\hline 1 & $\begin{array}{l}\text { Is tolerance correcting as per manufacturing } \\
\text { capability? }\end{array}$ & & & & & \\
\hline 2 & $\begin{array}{l}\text { Have all CTQs been identified on the draw- } \\
\text { ing? }\end{array}$ & & & & & \\
\hline 3 & $\begin{array}{l}\text { Is a bill of material complete and a part of } \\
\text { the drawing? }\end{array}$ & & & & & \\
\hline 4 & $\begin{array}{l}\text { Are reference dimensions identified to re- } \\
\text { duce inspection? }\end{array}$ & & & & & \\
\hline 5 & $\begin{array}{l}\text { Are there any specifications specified that } \\
\text { cannot be evaluated using known inspec- } \\
\text { tion techniques? }\end{array}$ & & & & & \\
\hline 6 & $\begin{array}{l}\text { Are all material characteristics identified } \\
\text { and specified on the drawing? }\end{array}$ & & & & & \\
\hline 7 & $\begin{array}{l}\text { Are all dimensions that affect fit, function } \\
\text { and durability identified and tolerance spec- } \\
\text { ified? }\end{array}$ & & & & & \\
\hline
\end{tabular}


Table 3

Check Sheet (2) for Feasibility

\begin{tabular}{|c|c|c|c|c|c|c|}
\hline $\begin{array}{c}\text { Num- } \\
\text { ber }\end{array}$ & Particulars & Yes & No & Action Required & Responsibility & Date \\
\hline 1 & $\begin{array}{l}\text { Is selected process feasible for manufac- } \\
\text { ture? a. Technically b. Cost wise }\end{array}$ & & & & & \\
\hline 2 & What inputs will the supplier need? & & & & & \\
\hline 3 & Are needed inputs provided? & & & & & \\
\hline 4 & $\begin{array}{l}\text { What is supplier's feedback on achieving } \\
\text { critical to quality for process? }\end{array}$ & & & & & \\
\hline 5 & $\begin{array}{l}\text { Is there any process capability study done } \\
\text { on the process? }\end{array}$ & & & & & \\
\hline 6 & $\begin{array}{l}\text { What tolerance the supplier will be com- } \\
\text { fortably achieving? }\end{array}$ & & & & & \\
\hline 7 & $\begin{array}{l}\text { Is supplier capable of measuring Critical to } \\
\text { Quality? }\end{array}$ & & & & & \\
\hline 8 & $\begin{array}{l}\text { Does supplier possess sufficient capacity to } \\
\text { handle forecasted production? }\end{array}$ & & & & & \\
\hline
\end{tabular}

\section{Table 4}

Check Sheet (3) for Process Mapping

\begin{tabular}{|c|c|c|c|c|c|c|}
\hline Number & Particulars & Yes & No & Action Required & Responsibility & Date \\
\hline 1 & $\begin{array}{l}\text { Does flow chart illustrate sequence of } \\
\text { production and inspection? }\end{array}$ & & & & & \\
\hline 2 & $\begin{array}{l}\text { Does flow chart identify all the KPIV and } \\
\text { the KPOV of the process? }\end{array}$ & & & & & \\
\hline 3 & $\begin{array}{l}\text { Have provisions been made to identify } \\
\text { and inspect reworked products before } \\
\text { use? }\end{array}$ & & & & & \\
\hline 4 & Is costing derived from the flow chart? & & & & & \\
\hline 5 & $\begin{array}{l}\text { Is there a separate flow chart for manu- } \\
\text { facture of tooling? }\end{array}$ & & & & & \\
\hline 6 & Are drawings available for tooling? & & & & & \\
\hline
\end{tabular}

\section{Table 5}

Check Sheet (4) for Control Plan

\begin{tabular}{|c|c|c|c|c|c|c|}
\hline Number & Particulars & Yes & No & Action Required & Responsibility & Date \\
\hline 1 & $\begin{array}{l}\text { Is control plan derived from flow chart, } \\
\text { FMEA, DOE and critical to quality require- } \\
\text { ments? }\end{array}$ & & & & & \\
\hline 2 & $\begin{array}{l}\text { Have all customer concerns been identified } \\
\text { on control plan? }\end{array}$ & & & & & \\
\hline 3 & Are all critical Xs identified? & & & & & \\
\hline 4 & $\begin{array}{l}\text { Is percent contribution of } \mathrm{X} \text { with respect to } \\
\mathrm{Y} \text { identified? }\end{array}$ & & & & & \\
\hline 5 & $\begin{array}{l}\text { Is appropriate statistical control method } \\
\text { identified for the critical Xs? }\end{array}$ & & & & & \\
\hline 6 & $\begin{array}{l}\text { Are material specifications requiring in- } \\
\text { spection identified? }\end{array}$ & & & & & \\
\hline 7 & $\begin{array}{l}\text { Does control plan address incoming through } \\
\text { processing and assembly, including pack- } \\
\text { ing? }\end{array}$ & & & & & \\
\hline 8 & $\begin{array}{l}\text { Are functional testing requirements identi- } \\
\text { fied? }\end{array}$ & & & & & \\
\hline
\end{tabular}


There are many charts/graphs that are used to make sure the Design for Six Sigma is working appropriately for the company it is designed for. The graphs/charts as shown in Fig. 4 are examples of what managers and engineers use to make sure the plan is working for them (Idris et al., 1996; Van Iwaarden et al., 2008; Sunder, 2013b; Hu et al., 2008; Burnette, 2009).
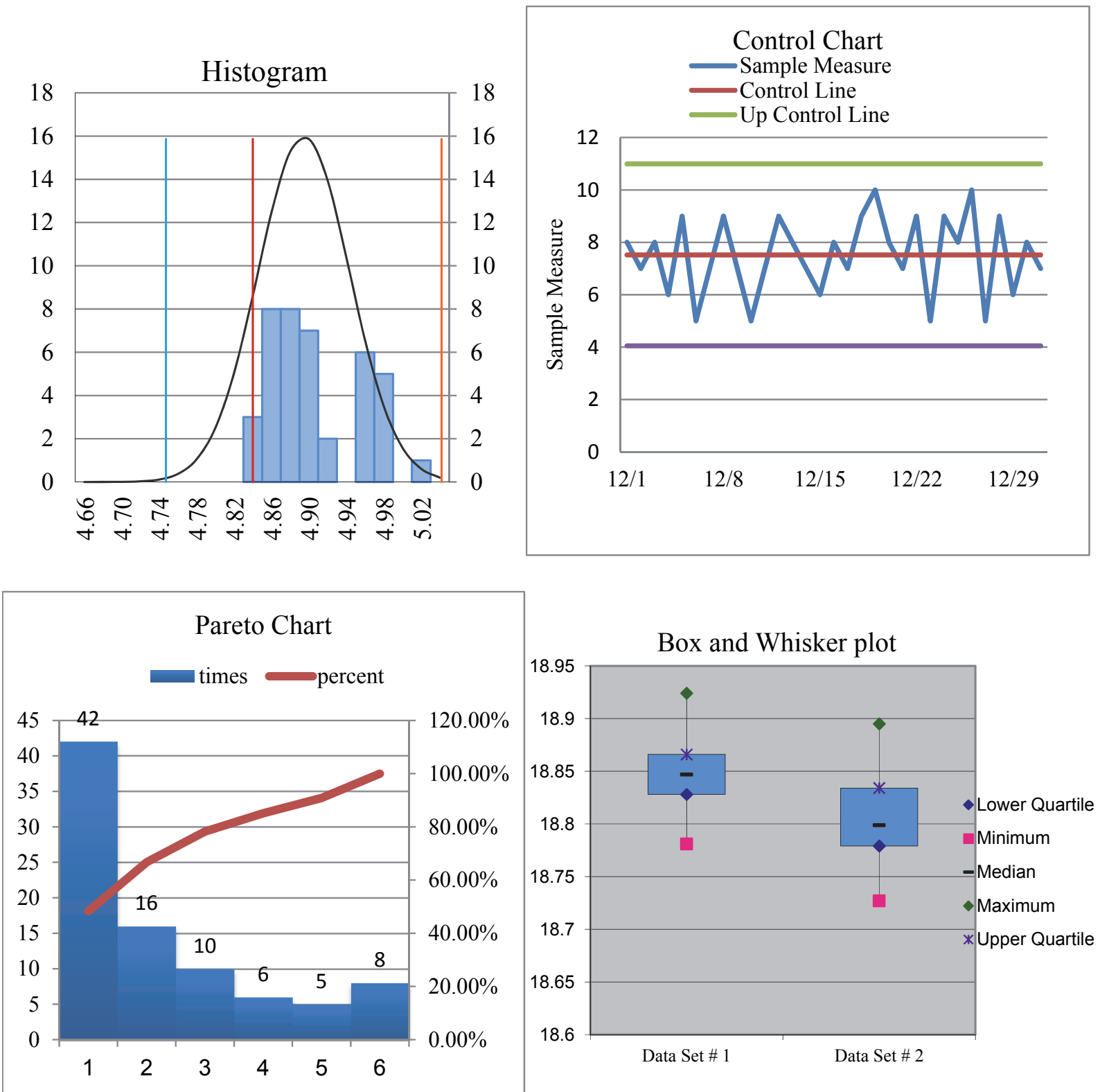

\subsection{Quality Management System}

Fig. 4. Charts and Graphs used in DFSS

Six Sigma and Design for Six Sigma (DFSS) are important parts of an overall strategy of continuous improvement for the consistent production of quality goods and services in the global marketplace (De Feo \& Bar, 2002). This strategy allows corporations to maintain and enhance a competitive advantage so that they successfully complete in the global market place. Continuous improvement techniques such as Total Quality Management (TQM) (Martínez-Lorente \& Dewhurst, 1998; Escanciano et al., 2002; Yang \& Yeh, 2007), Six Sigma, Design for Six Sigma (DFSS), Kaizen, Theory of Constraints and Lean Enterprise support the Quality System (Kumar, 2009, 2011; Pavlović et al., 2014; Savage, 2007). The quality system is the underlying network that supports quality assurance and improvement 
functions of successful corporations in every sector of business today. The Quality Management System (QMS) manages and administers the quality function (Rusjan \& Alič, 2010; Psomas et al., 2010; Van den Heuvel et al., 2005). This commitment to quality is often stated in a quality policy for an organization. The policy is usually expresses management's commitment to quality and how quality will be achieved in the corporations at all levels. The term "system" means that there are functional elements, attributes, processes and relationships. The quality system includes fourteen elements including: quality in marketing, quality in specification and design, quality in purchasing, quality of processes, product verification, control of inspection, measuring and test equipment, control of nonconforming product, corrective action, postproduction activities, quality records, personnel, product safety, and use of statistical methods (Polhemus, 2009).

The ISO 9000 Series is a set of international standards for quality management and quality assurance (Pun et al., 1999; Tsiotras \& Gotzamani, 1996; Jones et al., 1997; Belavendram, 1996; Bossert, 2013; Buttle, 1997; Zeng et al., 2005). The standards were developed to help companies effectively document the elements they need to maintain an efficient quality system to produce consistent goods and service that meet or exceed the quality requirements of their customers (Bozena et al., 2003). The standards are not specific to any one industry. ISO 9000 can help a company satisfy its customers, meet regulatory requirements, and achieve continual improvement (Sun, 2000; Singels et al., 2001; Escanciano \& Esteban, 2001; Rodrigues et al., 2009; Tang \& Kam, 1999). In the ISO 9000 family there are eight quality management principles that govern the Quality Management System: customer focus, leadership, involvement of people, process approach, systems approach to management, continual improvement, factual approach to decision making, and mutually beneficial supplier relationships (Zeng et al., 2007; Magd, 2008; Bradley, 1994; Feng et al., 2008). These eight quality management principles are similar to the previously mentioned quality system elements. Customers' focus means that an organization fully understands the requirements and expectations of its customers and they strive to meet these in all of their daily work (Gijo \& Rao, 2005). It is the job of top management to provide leadership to establish unity of purpose and direction in the corporation. Leadership must also support the QMS for it to be successful. The involvement of people at all levels of the organization is critical. All employees must be aware and engaged with the quality function. The process approach involves the inputs, outputs and the processes that drive all quality related elements. The process approach allows a process to be analyzed based on methods, materials, people, and other factors. All true processes should be measureable so that the effectiveness can be determined. The systems approach to management is used to identify the interrelated processes and how they affect each other. Continuous improvement relies on a mindset that all processes, people and products can be improved. Continuous improvement utilizes the Define, Measure, Analyze, Improve and Control (DMAIC) process (Schall, 2012; Chang et al., 2012; Jing \& Li, 2004). It an integral part of a Six Sigma initiative (Georgakopoulos, 2001; Sigma designs announces MPEG-4 decoder chip, 2001), but it can also be implemented as a standalone quality improvement procedure or as part of other process improvement initiatives such as lean (Banking with lean Six Sigma, 2015). A factual approach to decision making is one where data and information are used to guide decisions. Mutually beneficial supplier relationships acknowledge that many times organizations are only as good as their suppliers. Suppliers and customers are dependent on each other and this mutually beneficial relationship helps both parties to add value.

The ISO 9001:2008 standard is a document that prescribes a set of requirements that organizations must satisfy in order to achieve the ISO 9001 registration (Campatelli et al., 2011; Chow-Chua et al,, 2003). This registration is required in some industries and it is highly desired in several other industries in the global marketplace. The current version of this standard is the ISO 9001:2008, although the next version is set to be published in summer of 2015. AS9100 revision D is the quality management system standard for the aerospace industry. It incorporates all the requirements of the ISO 9001:2008 standard and adds some additional requirements specific to the aerospace industry. Some of these requirements are risk management, configuration management and more stringent controls in purchasing and supplier management. The next revision of the AS9100 standard is also scheduled to be released in 2015 
(Almaoui et al., 2013). Products and services delivered by ISO 9001 and AS 9100 registered companies give consumers added assurance that they are receiving a quality product or service made to requirements and it meets or exceeds their quality expectation. A typical quality management system flowchart is shown in Fig. 5 (Heras et al., 2002; Magd, 2008; Apley \& Kim, 2011; Tan et al., 2003).

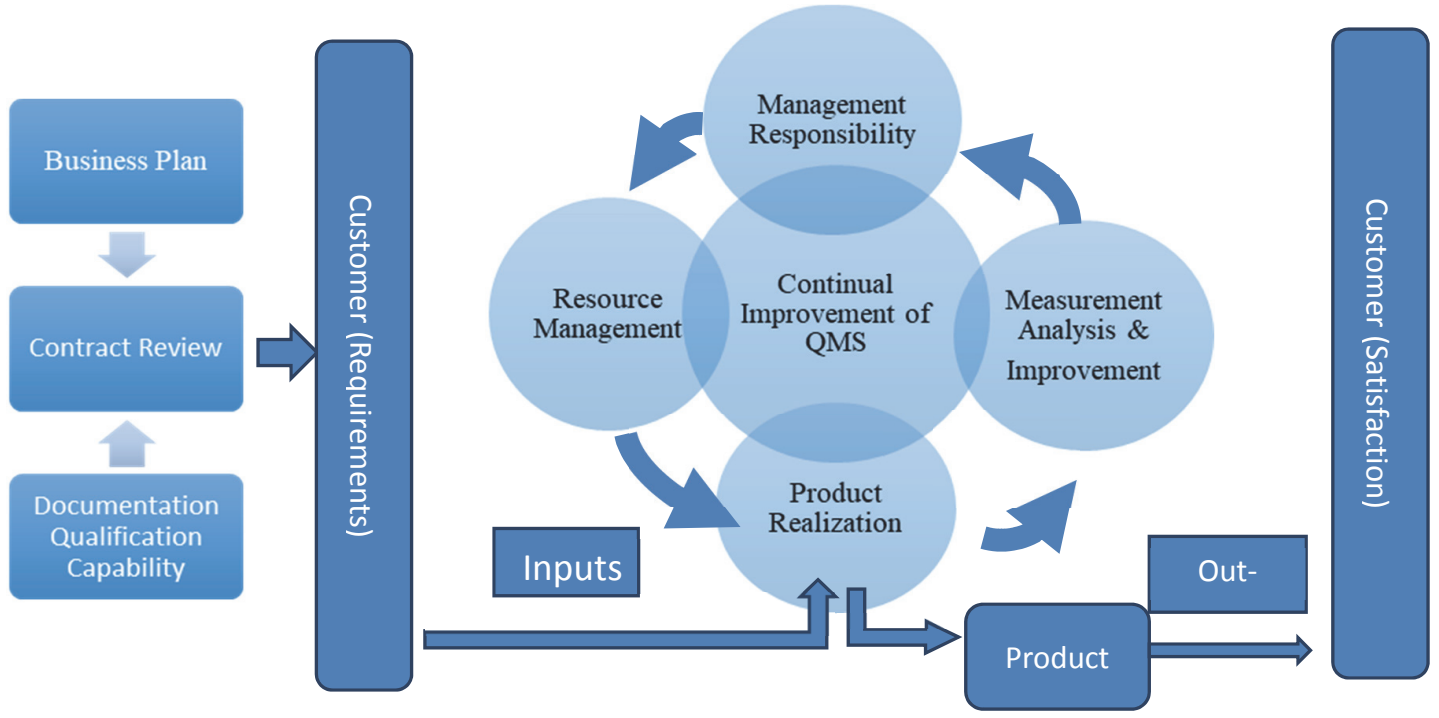

Fig. 5. Quality Management System Process Flowchart

Top management has to be a part of a successful QMS. An example of the top management responsibilities is shown in Fig. 6 (Karthi et al., 2012; Magd, 2008; Biazzo \& Bernardi, 2003).

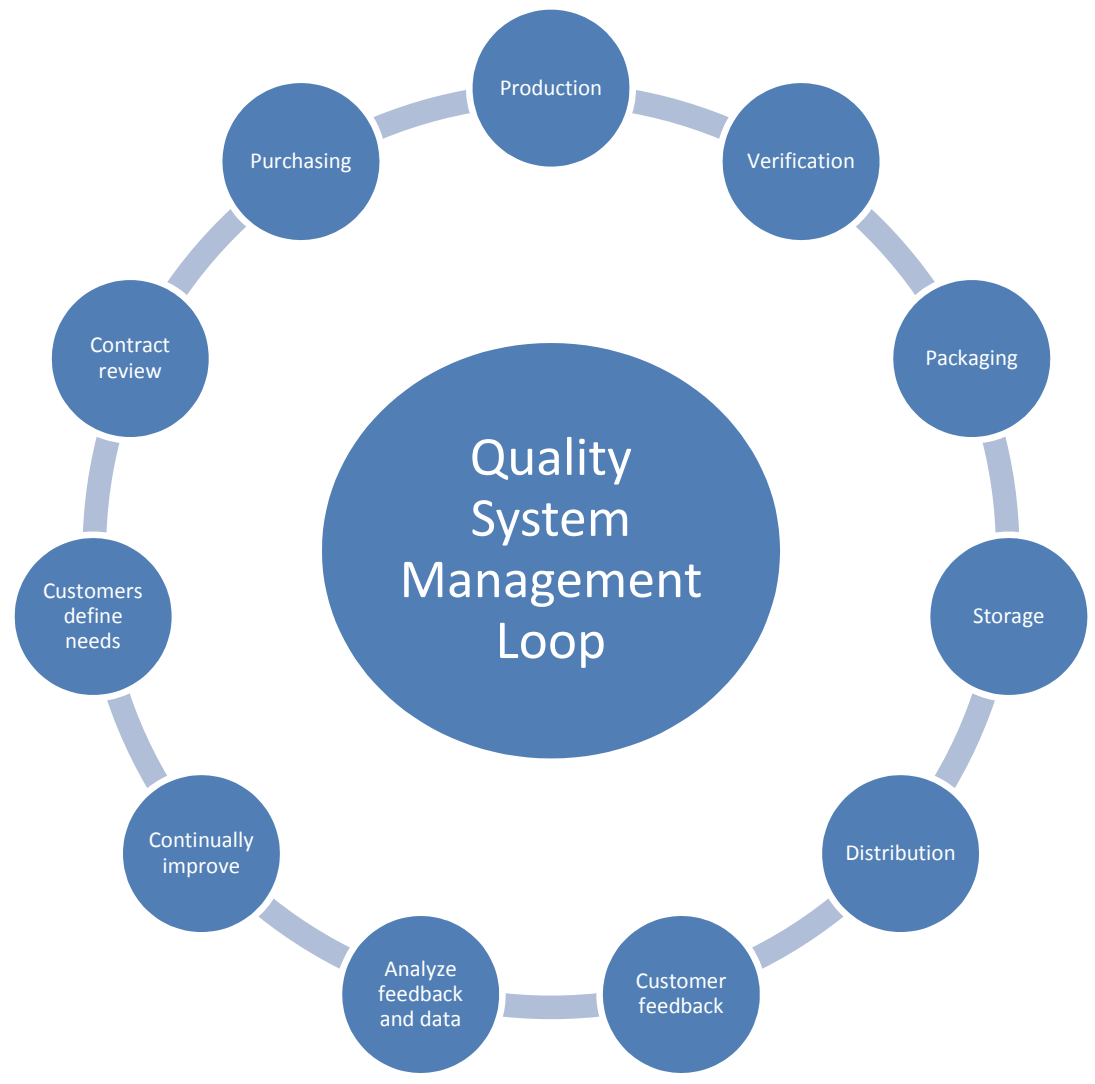

Fig. 6. The Top Management Responsibilities 
Create an environment where people are fully involved and in which a quality management system can operate effectively.

$>$ To establish and maintain the quality policy and quality objectives of the organization.

$>$ To promote the quality policy and quality objectives throughout the organization to increase awareness, motivation and involvement.

$>$ To ensure focus on customer requirements throughout the organization.

$>$ To ensure that appropriate processes are implemented to enable requirements of customers and other interested parties to be fulfilled and quality objectives to be achieved.

The quality system document structure is key to a successful QMS (Jou, 2010). An example is shown in Fig. 7 (De Feo \& Bar-El, 2002).

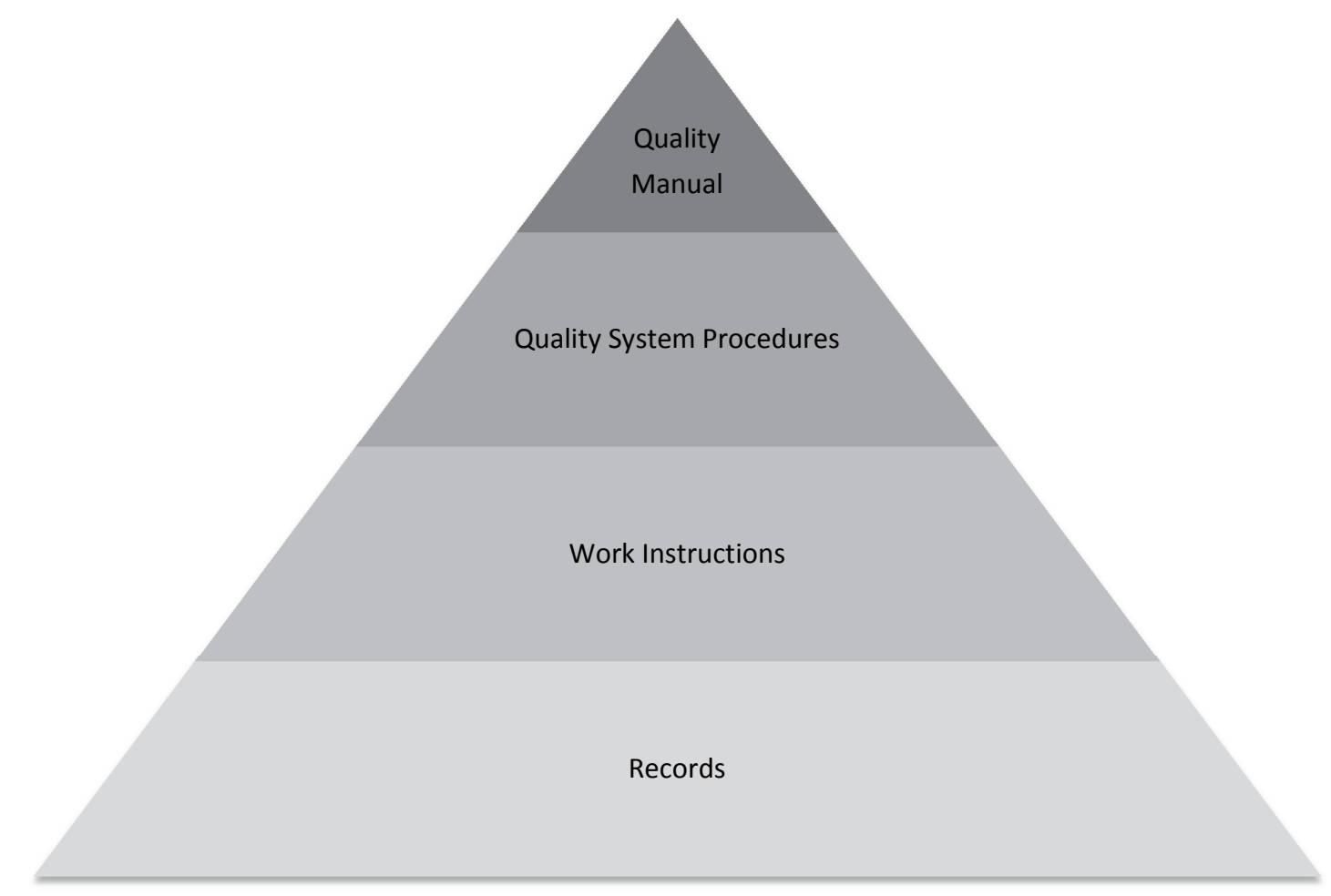

Fig. 7. Quality System Document Structure

\section{$>$ Control of documents}

- Ensure documents are approved before use

- Ensure current revision status is controlled

- Maintain master list of documents

- Prevent use of obsolete documents

- Issue controlled copies

$>$ Photocopies of controlled documents are NOT ALLOWED

$>$ Control of records (Tan et al., 2003)

Evidence of conformance to specified requirements and effective operation.

The organization must have an overall quality vision that includes the QMS. Fig. 8 is an example (Kemper \& De Mast, 2013). 


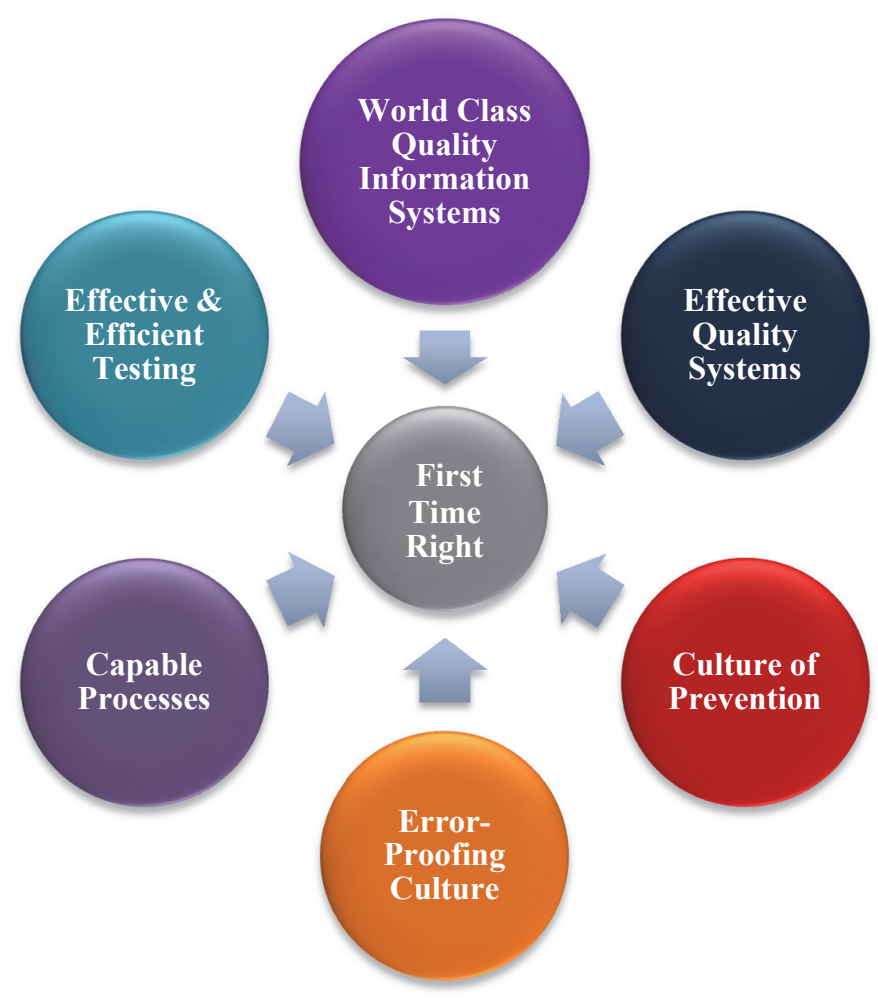

Fig. 8. An Overall Quality Vision

\section{Conclusion}

There are several reasons to purchase and implement a Six Sigma program into an organization. The main purpose of a Six Sigma program is to improve throughput, which in term will increase the overall revenue (Kemper \& De Mast, 2013). The way that it improves your throughput is that it reduces the number of defects in the process of production. By reducing defects it improves throughput. With the improvement of throughput it positively affects the bottom line of an organization. The only downside to a Six Sigma program is the initial cost and the continued cost of training and keeping it going. An organization has to decide if the overhead cost is worth the long term reward of having a Six Sigma program. If the organization is in it for the long haul then a Six Sigma program is financially beneficial. If a company cannot afford a Six Sigma program then they need to implement some form of total quality management (Johnson, 2006). Six Sigma implementation has some major complications that start with management's commitment and cost (Poksinska et al., 2003; Chow-Chua et al., 2003; Brue, 2005). This review went into far more comprehensive analysis of Six Sigma implementation that showed these complication factors are common among all organizations agreeing Six Sigma program was a financially sound decision. Also, Six Sigma program has some limitations such as being deeply depended on the evaluation of pilot lots and assessment of all critical process capabilities. Furthermore, Design for Six Sigma requires to be subjectively assessed through Drawing Sheet, Feasibility Checklist, Process Mapping, and Control Plan Sheet. This type of assessment is some sort of limitation for this program in an organization. For future work, one may explore integration methodology that mitigates the current complication and limitation.

\section{References}

Aksoy, E., \& Dincmen, M. (2011). Knowledge focused Six Sigma (KFSS): a methodology to calculate Six Sigma intellectual capital. Total Quality Management, 22(3), 275-288. 
Almaoui, M., Saouli, M. A., \& Sinha, B. R. (2013). Implementation of Quality Objectives in ISO 9001/AS9100 Organizations and Impact on Customer Satisfaction. Journal of Management \& Engineering Integration, 6(1), 106.

Anand, R. B., Shukla, S. K., Ghorpade, A., Tiwari, M. K., \& Shankar, R. (2007). Six sigma-based approach to optimize deep drawing operation variables. International Journal of Production Research, 45(10), 2365-2385.

Apley, D. W., \& Kim, J. (2011). A cautious approach to robust design with model parameter uncertainty. IIE Transactions, 43(7), 471-482.

Atkinson, P. (2014). DMAIC: A methodology for Lean Six Sigma business transformation. Management Services, 58(1), 12-17.

Banking with lean Six Sigma. (2015). Industrial Engineer: IE, 47(2), 15.

Biazzo, S., \& Bernardi, G. (2003). Process management practices and quality systems standards: risks and opportunities of the new ISO 9001 certification. Business Process Management Journal, 9(2), 149-169.

Bhuiyan, N., \& Alam, N. (2004). ISO 9001: 2000 implementation-the North American experience. International Journal of Productivity and Performance Management, 53(1), 10-17.

Boisvert, M. M. (2005). Dartmouth and SMT unite for Six Sigma program. SMT: Surface Mount Technology, 19(3), 4.

Bossert, J. (2013). Six Sigma stifles innovation? No!. Journal For Quality \& Participation, 36(3), 3940.

Barbara, B. S., Solomon, M. R., \& Stinerock, R. (1992). Surrogate Money Managers in the 1990s: Marketing Strategy for Financial Services Retailers. Service Industries Journal, 12(1), 78-96.

Bradley, M. (1994). Starting total quality management from ISO 9000. The TQM Magazine, 6(1), 5054.

Brue, G. (2005). Will the real Six Sigma please stand up?. Adhesives \& Sealants Industry, 12(2), 3435.

Burnette, R. (2009). New Product Introduction-Feast or Famine?. The Journal of Business Forecasting, 28(4), 22.

Buttle, F. (1997). ISO 9000: marketing motivations and benefits. International journal of quality \& reliability management, 14(9), 936-947.

Campatelli, G., Citti, P., \& Meneghin, A. (2011). Development of a simplified approach based on the EFQM model and Six Sigma for the implementation of TQM principles in a university administration. Total Quality Management \& Business Excellence, 22(7), 691-704.

Canato, A., Ravasi, D., \& Phillips, N. (2013). Coerced practice implementation in cases of low cultural fit: Cultural change and practice adaptation during the implementation of Six Sigma at 3M. Academy of Management Journal, 56(6), 1724-1753.

Carney, S. (2001). Ford banks on Six Sigma to keep quality job one. Automotive News, 75(5913), 3838.

Caulcutt, R. (2001). Why is Six Sigma so successful?. Journal of Applied Statistics, 28(3-4), 301-306.

Chang, S. I., Tsai, T. R., Lin, D. K., Chou, S. H., \& Lin, Y. S. (2012). Statistical process control for monitoring nonlinear profiles: A six sigma project on curing process. Quality Engineering, 24(2), 251-263.

Chang, S. I., Yen, D. C., Chou, C. C., Wu, H. C., \& Lee, H. P. (2012). Applying Six Sigma to the management and improvement of production planning procedure's performance. Total Quality Management \& Business Excellence, 23(3-4), 291-308.

Chen, K. S., Lin, C. T., \& Chen, S. C. (2008). Applying Six-Sigma methodology in constructing the quick response of a case reporting system. Total Quality Management, 19(4), 381-398.

Chou, C. Y., Chen, C. H., \& Liu, H. R. (2005). Acceptance control charts for non-normal data. Journal of Applied Statistics, 32(1), 25-36.

Chow-Chua, C., Goh, M., \& Boon Wan, T. (2003). Does ISO 9000 certification improve business performance?. International Journal of Quality \& Reliability Management, 20(8), 936-953. 
Chen, K. S., Chen, H. T., \& Lin, C. L. (2012). Applying a revised SQPM in the define step of six sigma and a case study. Total Quality Management \& Business Excellence, 23(3-4), 309-324.

Chung, Y. C., \& Hsu, Y. W. (2010). Research on the correlation between Design for Six Sigma implementation activity levels, new product development strategies and new product development performance in Taiwan's high-tech manufacturers. Total Quality Management, 21(6), 603-616.

Davison, L., \& Al-Shaghana, K. (2007). The link between Six Sigma and quality culture-an empirical study. Total Quality Management \& Business Excellence, 18(3), 249-265.

De Feo, J., \& Bar-El, Z. (2002). Creating strategic change more efficiently with a new design for six sigma process. Journal of Change Management, 3(1), 60-80.

Dick, G. P., Heras, I., \& Casadesús, M. (2008). Shedding light on causation between ISO 9001 and improved business performance. International Journal of Operations \& Production Management, 28(7), 687-708.

Eckes, G. (2003). Making six sigma last (and work). Ivey Business Journal, 68(2), 1-5.

Escanciano, C., Fernández, E., \& Vázquez, C. (2001). ISO 9000 certification and quality management in Spain: results of a national survey. The TQM Magazine, 13(3), 192-200.

Feng, M., Terziovski, M., \& Samson, D. (2007). Relationship of ISO 9001: 2000 quality system certification with operational and business performance: A survey in Australia and New Zealand-based manufacturing and service companies. Journal of manufacturing technology management, 19(1), 22-37.

Flynn, B. B., Schroeder, R. G., \& Sakakibara, S. (1995). The impact of quality management practices on performance and competitive advantage. Decision sciences, 26(5), 659-691.

Furterer, S., \& Elshennawy, A. K. (2005). Implementation of TQM and lean Six Sigma tools in local government: a framework and a case study. Total Quality Management \& Business Excellence, 16(10), 1179-1191.

Galli, B. J., \& Handley, H. (2014). The right approach to Six Sigma leadership. Industrial Management, $56(3), 25-30$.

Georgakopoulos, E. (2001). Conseco moves full speed ahead with six sigma. Best's Review, 102(7), 58-58.

Gijo, E. V., \& Rao, T. S. (2005). Six Sigma implementation-hurdles and more hurdles. Total Quality Management \& Business Excellence, 16(6), 721-725.

Goh, T. N. (2010). Six triumphs and six tragedies of Six Sigma. Quality Engineering, 22(4), 299-305.

Gowen III, C. R., Stock, G. N., \& McFadden, K. L. (2008). Simultaneous implementation of Six Sigma and knowledge management in hospitals. International Journal of Production Research, 46(23), 6781-6795.

Grant, D., \& Mergen, A. E. (2009). Towards the use of Six Sigma in software development. Total Quality Management, 20(7), 705-712.

Guarraia, P., Carey, G., Corbett, A., \& Neuhaus, K. (2009). Six Sigma-at your service. Business Strategy Review, 20(2), 56-61.

Gutiérrez, L. G., Bustinza, O. F., \& Molina, V. B. (2012). Six sigma, absorptive capacity and organisational learning orientation. International Journal of Production Research, 50(3), 661-675.

Gutiérrez, L. J. G., Torres, I. T., \& Molina, V. B. (2010). Quality management initiatives in Europe: An empirical analysis according to their structural elements. Total Quality Management, 21(6), 577 601.

Halliday, S. (2001). So what exactly is...Six Sigma?. Works Management, 54(1), 15.

Herman, J. (2007). Six Sigma is a key implement in the quality toolbox. Automotive News, 81(6267), 24.

Heras, I., Casadesús, M., \& Dick, G. P. (2002). ISO 9000 certification and the bottom line: a comparative study of the profitability of Basque region companies. Managerial Auditing Journal, 17(1/2), 72-78.

Hu, G., Wang, L., Fetch, S., \& Bidanda, B. (2008). A multi-objective model for project portfolio selection to implement lean and Six Sigma concepts. International journal of production research, 46(23), 6611-6625. 
Idris, M. A., McEwan, W., \& Belavendram, N. (1996). The adoption of ISO 9000 and total quality management in Malaysia. The TQM Magazine, 8(5), 65-68.

Isakson, M. (2004). Applying six sigma to your organization: Benefits and considerations. Franchising World, 36(4), 25-26.

Jing, G., G., \& Li, N. (2004). Claiming Six Sigma. Industrial Engineer: IE, 36(2), 37-39.

Johnson, A. (2006). Lessons learned from Six Sigma in R\&D. Research-Technology Management, 49(2), 15-19.

Johnson, J. A., Gitlow, H., Widener, S., \& Popovich, E. (2006). Designing New Housing at the University of Miami: A "Six Sigma”C DMADV/DFSS Case Study. Quality Engineering, 18(3), 299323.

Jolin, J. J. (2009). Risk Assessments Six Sigma Style. Internal Auditor, 66(6), 37-41.

Jones, R., Arndt, G., \& Kustin, R. (1997). ISO 9000 among Australian companies: impact of time and reasons for seeking certification on perceptions of benefits received. International Journal of Quality \& Reliability Management, 14(7), 650-660.

Jones, E. C., Parast, M. M., \& Adams, S. G. (2010). A framework for effective Six Sigma implementation. Total quality management, 21(4), 415-424.

Jou, Y. T., Chen, C. H., Hwang, C. H., Lin, W. T., \& Huang, S. J. (2010). A study on the improvements of new product development procedure performance-an application of design for Six Sigma in a semi-conductor equipment manufacturer. International journal of production research, 48(19), $5573-5591$.

Jusko, J. (2002, December). Prevention is the cure. Industry Week. 251(12), 86.

Kanigolla, D., Cudney, E. A., \& Corns, S. M. (2013). Employing project-based learning in Six Sigma education. The Journal for Quality and Participation, 36(1), 34.

Karthi, S., Devadasan, S. R., Murugesh, R., Sreenivasa, C. G., \& Sivaram, N. M. (2012). Global views on integrating Six Sigma and ISO 9001 certification. Total Quality Management \& Business Excellence, 23(3-4), 237-262.

Kemper, B., \& de Mast, J. (2013). Measurement plans for process flow improvement in services and health care. Quality Engineering, 25(4), 437-450.

Kihn, M. (2005). Six Sigma Stigma?. Fast Company, 98, 40.

Krishnamoorthi, K. S. (2011). What, why, and how: the importance of statistical thinking for Six Sigma. Industrial Engineer, 43(10), 28-34.

Kuei, C. H., Madu, C. N., \& Lin, C. (2011). Developing global supply chain quality management systems. International Journal of Production Research, 49(15), 4457-4481.

Kumar, M., Antony, J., \& Tiwari, M. K. (2011). Six Sigma implementation framework for SMEs-a roadmap to manage and sustain the change. International Journal of Production Research, 49(18), 5449-5467.

Kumar, S., Phillips, A., \& Rupp, J. (2009). Using Six Sigma DMAIC to design a high-quality summer lodge operation. Journal of Retail \& Leisure Property, 8(3), 173-191.

Magd, H. A. (2008). ISO 9001: 2000 in the Egyptian manufacturing sector: perceptions and perspectives. International Journal of Quality \& Reliability Management, 25(2), 173-200.

Martínez-Lorente, A. R., Dewhurst, F., \& Dale, B. G. (1998). Total quality management: origins and evolution of the term. The TQM Magazine, 10(5), 378-386.

McAdam, R., \& Evans, A. (2004). Challenges to Six Sigma in a high technology mass-manufacturing environments. Total Quality Management \& Business Excellence, 15(5-6), 699-706.

Meeting and show. (2009, February). Machine Design. 81(3), 29-29.

Moosa, K., \& Sajid, A. (2010). Critical analysis of Six Sigma implementation. Total Quality Management, 21(7), 745-759.

Nandi, A., Pan, S., Potumarthi, R., Danquah, M. K., \& Sarethy, I. P. (2014). A proposal for six sigma integration for large-scale production of penicillin $\mathrm{g}$ and subsequent conversion to 6-APA. Journal of analytical methods in chemistry, 2014.

O'Neill, J., Atkins, G., Curbison, D., Flak, B., Lucas, J. M., Metzger, D., ... \& Wiener, M. C. (2012). Statistical Engineering to Stabilize Vaccine Supply. Quality Engineering, 24(2), 227-240. 
Owens, D. (2011). Successful measures. Using Six Sigma to implement a work-request system. Health facilities management, 24(2), 27-30.

Parihar, S., \& Bhar, C. (2014). Six Sigma, the cloud and clarity. Industrial Engineer: IE, 46(10), 4448.

Park, S., \& Gil, Y. (2006). How Samsung transformed its corporate R\&D center. Research-Technology Management, 49(4), 24-29.

Park, S. H., Ntuen, C. A., \& Park, E. H. (2009). A new paradigm of six sigma: knowledge-based digital six sigma. Total Quality Management, 20(9), 945-952.

Pavlović, D., Todorović, M., Mladenović, S., \& Milosavljević, P. (2014). The role of quality methods in improving education process: Case study. Serbian Journal of Management, 9(2), 219-230.

Pisani, M. J., Hayes, R., Kumar, A., \& Lepisto, L. (2009). Is Six Sigma culture bound? A conceptual model and propositions for further inquiry. Total Quality Management, 20(10), 1123-1137.

Plotkin, H. (1999). Six Sigma: What It Is and How to Use It. Harvard Management Update, 4(6), 6.

Polhemus, N. W. (2009). Selecting STATISTICAL Software for Six Sigma. Quality, 48(1), 62-64.

Poksinska, B., Jörn Dahlgaard, J., \& Eklund, J. A. (2003). Implementing ISO 14000 in Sweden: motives, benefits and comparisons with ISO 9000. International Journal of Quality \& Reliability Management, 20(5), 585-606.

Pun, K. F., Chin, K. S., \& Lau, H. (1999). A self-assessed quality management system based on integration of MBNQA/ISO 9000/ISO 14000. International Journal of Quality \& Reliability Management, 16(6), 606-629.

Psomas, E. L., Fotopoulos, C. V., \& Kafetzopoulos, D. P. (2010). Critical factors for effective implementation of ISO 9001 in SME service companies. Managing Service Quality: An International Journal, 20(5), 440-457.

Rajagopalan, R., Francis, M., \& Suárez, W. (2004). Managers at Work: Developing Novel Catalysts with Six Sigma. Research-Technology Management, 47(1), 13-16.

Ravichandran, J. (2006). Six-sigma milestone: an overall sigma level of an organization. Total quality management, 17(8), 973-980.

Rusjan, B., \& Alič, M. (2010). Capitalising on ISO 9001 benefits for strategic results. International Journal of Quality \& Reliability Management, 27(7), 756-778.

Sampaio, P., Saraiva, P., \& Guimarães Rodrigues, A. (2009). ISO 9001 certification research: questions, answers and approaches. International Journal of Quality \& Reliability Management, 26(1), $38-58$.

Singels, J., Ruël, G., \& Van De Water, H. (2001). ISO 9000 series-Certification and performance. International Journal of Quality \& Reliability Management, 18(1), 62-75.

Savage, G. J. (2007). Probability constrained optimization as a tool for functional design for six sigma. Quality Engineering, 19(2), 101-110.

Schall, S. O. (2012). Variability reduction: a statistical engineering approach to engage operations teams in process improvement. Quality Engineering, 24(2), 264-279.

Shah, R., Chandrasekaran, A., \& Linderman, K. (2008). In pursuit of implementation patterns: the context of Lean and Six Sigma. International Journal of Production Research, 46(23), 6679-6699.

Sigma designs announces MPEG-4 decoder chip. (2001). EMedia Magazine, 14(7), 18.

Sun, H. (2000). Total quality management, ISO 9000 certification and performance improvement. International Journal of Quality \& Reliability Management, 17(2), 168-179.

Snee, R. D. (2011). Understanding formulation systems-A Six Sigma approach. Quality Engineering, 23(3), 278-286.

Sunder, M. V. (2013a). Six Sigma-A Strategy for Increasing Employee Engagement. The Journal for Quality and Participation, 36(2), 34.

Sunder, M. V. (2013b). Synergies of lean six sigma. IUP Journal of Operations Management, 12(1), 21.

Tang, S. L., \& Kam, C. W. (1999). A survey of ISO 9001 implementation in engineering consultancies in Hong Kong. International Journal of Quality \& Reliability Management, 16(6), 562-574. 
Tan, B., Lin, C., \& Hung, H. C. (2003). An ISO 9001: 2000 quality information system in e-commerce environment. Industrial Management \& Data Systems, 103(9), 666-676.

Terziovski, M., \& Samson, D. (1999). The link between total quality management practice and organisational performance. International Journal of Quality \& Reliability Management, 16(3), 226-237.

Tsiotras, G., \& Gotzamani, K. (1996). ISO 9000 as an entry key to TQM: the case of Greek industry. International Journal of Quality \& Reliability Management, 13(4), 64-76.

Van den Heuvel, J., Koning, L., Bogers, A. J., Berg, M., \& van Dijen, M. E. (2005). An ISO 9001 quality management system in a hospital: bureaucracy or just benefits?. International Journal of Health Care Quality Assurance, 18(5), 361-369.

van Iwaarden, J., van der Wiele, T., Dale, B., Williams, R., \& Bertsch, B. (2008). The Six Sigma improvement approach: a transnational comparison. International Journal of Production Research, 46(23), 6739-6758.

Vasilash, G. S. (2003). High-performance computing, Boeing \& design for six sigma. Automotive Manufacturing and Production, 115(8), 27-27.

Wang, H. M. S., Wang, S. P., \& Lee, W. (2014). A case study for reducing client waiting time in a health evaluation center using design for Six Sigma. Engineering Management Journal, 26(2), 6273.

Yang, C. C., \& Yeh, T. M. (2007). An integrated model of Hoshin management and Six Sigma in hightech firms. Total Quality Management, 18(6), 653-665.

Zeng, S. X., Tian, P., \& Shi, J. J. (2005). Implementing integration of ISO 9001 and ISO 14001 for construction. Managerial Auditing Journal, 20(4), 394-407.

Zeng, S. X., Tian, P., \& Tam, C. M. (2007). Overcoming barriers to sustainable implementation of the ISO 9001 system. Managerial Auditing Journal, 22(3), 244-254.

Zhang, W., \& Xu, X. (2008). Six Sigma and information systems project management: A revised theoretical model. Project Management Journal, 39(3), 59-74.

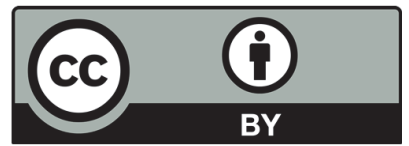

(C) 2017 by the authors; licensee Growing Science, Canada. This is an open access article distributed under the terms and conditions of the Creative Commons Attribution (CC-BY) license (http://creativecommons.org/licenses/by/4.0/). 